\title{
Interrelationships Between Chlorophylls, Carbon, Nitrogen and Heterotrophic Bacteria in an Intertidal Sediment Transect
}

\author{
J. G. Anderson ${ }^{1}$, P. Boonruang ${ }^{1}$ and P. S. Meadows ${ }^{2}$ \\ 1 Department of Applied Microbiology, University of Strathclyde, Glasgow, United Kingdom \\ ${ }^{2}$ Department of Zoology, University of Glasgow, United Kingdom
}

\begin{abstract}
An intertidal sand sediment was sampled over 6 months at 7 stations from extreme high tide to extreme low tide level. Vertical transects were conducted at MTL. Measurements were taken of carbon, nitrogen, chlorophylls $d, b$ and $c$ and of numbers (CFU) of heterotrophic bacteria. Surface sediment values were very low at EHWS and peaked at MHTL and MLTL. A comparison of ratios of assayed parameters showed that Station 1 (EHWS) was always different from Stations 3-7, whereas Station 2 was intermediate. Correlation and multıple linear regression analyses showed that carbon, nitrogen and chlorophylls $a, b$ and $c$ were highly correlated.
\end{abstract}

\section{INTRODUCTION}

There have been few attempts to assess the intertidal relationships between the chemical and microbiological properties of sandy intertidal sediments (Westheide, 1968; Pugh et al., 1974; Cadée and Hegeman, 1977; de Jonge, 1980). This information is of considerable importance to the ecology of microorganisms in sand, to energy flow in intertidal beaches and to food availability and habitat selection by sedimentary invertebrates (Steele and Baird, 1968; Meadows and Campbell, 1972; Rheinheimer, 1977; Munro et al., 1978).

The present paper quantifies the changes in carbon, nitrogen, chlorophylls $a, b$ and $c$, and colony forming units of heterotrophic bacteria that occur at the surface of a sandy sediment between high and low tide levels. Relationships between these parameters are analysed by correlation and multiple linear regression. The authors are aware of no previous analyses of intertidal transect work as reported in this paper.

\section{MATERIALS AND METHODS}

Sand samples were collected from Southannan Sands near Fairlie in the Clyde Estuary (National Grid reference number NS 204540) (Fig. 1). Seven intertidal sampling stations were selected: Station, 1, high water springs level; Station 2, mean high tide level; Station 3, upper intertidal zone; Station 4, mid-tide level; Station 5, lower intertidal zone; Station 6, mean low tide level; Station 7, low water springs level. Drift line seaweed and intertidal seagrass (Spartina) were present at Station 2. Many casts and burrows of Arenicola marina, Nereis diversicolor and Cardium edule were present at Stations 3, 4 and 5. The sand at Station 6 was interspersed with fragments of mollusc shells. The sediment mean particle size was $271 \pm 129 \mu \mathrm{m}$.

The distances of the stations from Station 1 were as follows: Station 2, $9 \mathrm{~m}$; Station 3, $91 \mathrm{~m}$; Station 4, $229 \mathrm{~m}$; Station 5, $366 \mathrm{~m}$; Station 6, $411 \mathrm{~m}$; Station 7 . $503 \mathrm{~m}$.

Sand was collected using sterile precautions, and kept at $4{ }^{\circ} \mathrm{C}$. It was taken from the surface layer of sediment $(<0.5 \mathrm{~cm})$ and also at depths of $5 \mathrm{~cm}$ and $10 \mathrm{~cm}$ at mid tide level (Station 4). Measurements were conducted immediately on return to the laboratory. Two measurements of chlorophyll pigments, carbon, nitrogen and colony forming units (CFU) of heterotrophic bacteria were taken on each aliquot of sand. One aliquot of sand was taken from each station at each of 8 sampling times between March and July at approximately fortnightly intervals except at Station 7. where only 5 samples were taken because the station was not always exposed. There were no obvious sea- 


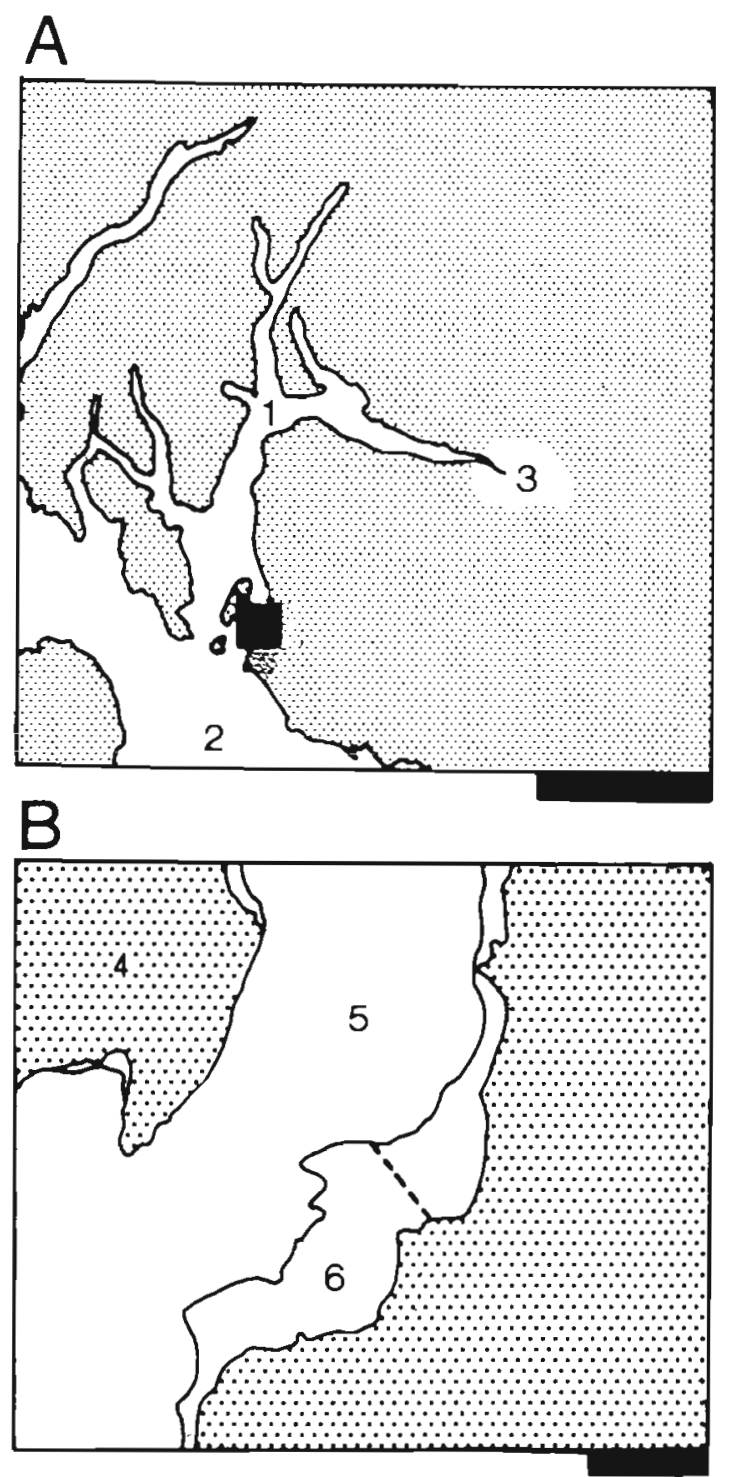

Fig. 1. Location of sampling site. (A) Clyde Estuary and Sea Area. Black bar $=20 \mathrm{~km}$. (B) Precise location of intertidal transect on Southannan Sands (corresponds to black rectangle in $\mathrm{A}$ ). Dashed line in $\mathrm{B}$ : intertidal transect on Southannan Sands. Bar $=1 \mathrm{~km}$. 1: Clyde Estuary; 2 : Clyde Sea Area; 3: Glasgow; 4: Island of Cumbrae; 5: Fairlie Roads; 6: Intertidal sand

sonal changes. The temperature of the sediment surface increased from $6^{\circ} \mathrm{C}$ in March to $18^{\circ} \mathrm{C}$ in July.

Chlorophylls $a, b$, and $c$ were estimated by acetone extraction of $1-5 \mathrm{~g}$ of sand (Parsons and Strickland, 1963; Strickland and Parsons, 1968). Precautions were taken to minimise the oxidation of chlorophyll by light during extraction. Nitrogen was measured by a microKjeldahl method (Strickland and Parsons, 1968); $4 \mathrm{~g}$ of sand were ultrasonicated in $25 \mathrm{ml}$ distilled water for 30 min at $0-5{ }^{\circ} \mathrm{C}$ using a $100 \mathrm{w}$ ultrasonic disintegrator (M.S.E., cat. no. 7100). The nitrogen estimation was done on the supernatant. Preliminary optical density measurements showed that most of the material on sand grains was released within $30 \mathrm{~min}$ by this method, and that material was more quickly released by ultrasonication than by a Mickle homogenizer. Carbon was measured by dichromate oxidation (Strickland and Parsons, 1968) on 1-2 g aliquots of sand previously washed with $20 \mathrm{ml}$ distilled water and $10 \mathrm{ml}$ sodium sulphate solution.

Colony forming units (CFU) of heterotrophic bacteria were estimated by the surface spread plate technique using Bacto-Marine agar 2216 (Difco). Counts were made after $14 \mathrm{~d}$ incubation at $22^{\circ} \mathrm{C}$. To obtain counts $25 \mathrm{ml}$ of sterile $75 \%$ artificial seawater was added to $4 \mathrm{~g}$ aliquots of sand and ultrasonicated for $1 \mathrm{~min}$ using the ultrasonic disintegrator. Preliminary experiments showed that most sand bacteria were released from particles within $1 \mathrm{~min}$ using this method, and that ultrasonication yielded much higher viable counts than shaking with distilled or sea water, or with sea water and tween $80(10 \mathrm{ppm})$.

\section{RESULTS}

\section{Comparison of Surface Sediment at Stations 1-7}

Fig. 2 shows the results obtained at Stations 1 to 7 The pattern of changes in the surface sediment down the beach was similar for all variables measured, except the heterotrophic bacteria (CFU). Very low values were obtained at the high water springs level (Station 1). There was a peak at the mean high tide station (Station 2), a trough at about mid tide level (Station 4), another peak at the mean low tide station (Station 6) and a decrease at the low water springs level (Station 7). These patterns of change were statistically significant (detailed analyses were conducted with a series of one way anovars and students t test). The heterotrophic bacterial (CFU) counts did not follow this pattern. Statistical analyses showed that there was no difference in the bacterial (CFU) counts between Stations 1, 3, 4, 5, 6 and 7 (one way analysis of variance with 6 levels; $F=2.073$, d. f. 5, 33, $p \approx 0.10$ ), but that the results at Station 2 (mean high tide level) were significantly higher than those from the rest of the beach (one way analysis of variance with 2 levels: $\mathrm{F}=19.91$, d. f. $1,44, \mathrm{p}<0.001$ )

Carbon/nitrogen, carbon/chlorophyll a, chlorophyll a/chlorophyll b, chlorophyll a/chlorophyll $c$ and nitrogen/heterotrophic (CFU) counts were calculated for Stations 1-7 (Fig 3). Differences between the stations were analysed by a series of one way analyses of variance for each of the ratios in turn. There was no difference between Stations 3-7 for any of the ratios. The ratios at Station 1 were always different from 


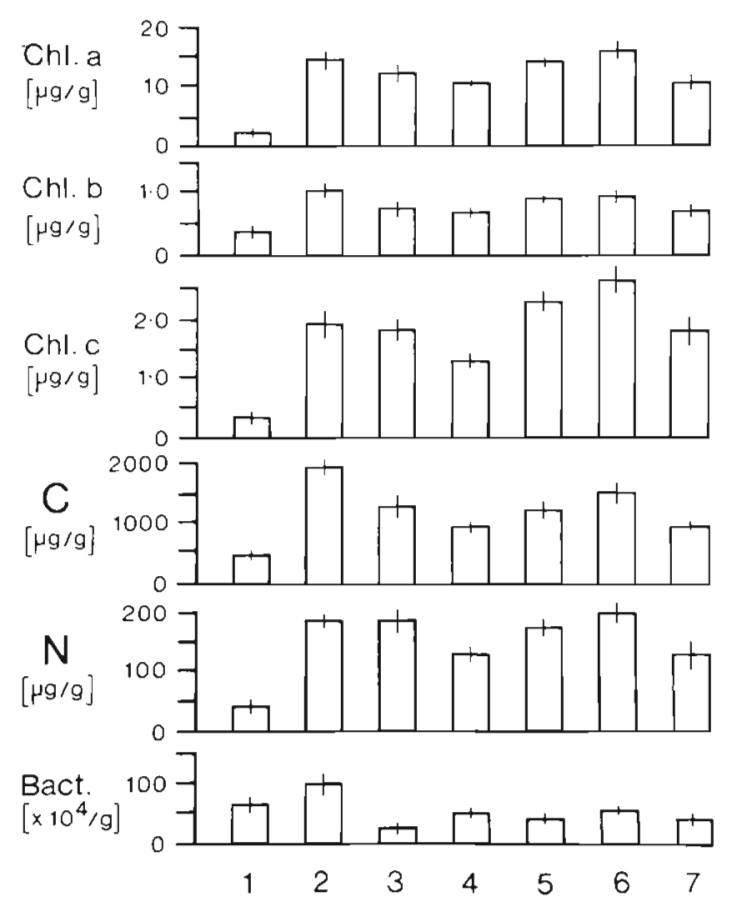

Fig. 2. Changes in chlorophylls, carbon, nitrogen and heterotrophic bacteria (CFU) in surface sediment at Stations 1-7 Bars: standard errors. For chlorophyll $a, b, c$ and heterotrophic bacteria (CFU) each column is the mean of 32 readings, except at Station 7 which is the mean of 20 readings. For carbon and nitrogen each column is the mean of 16 readings. except at station 7 which is the mean of 10 readings

Stations 3-7 (higher values of carbon/nitrogen, carbon/ chlorophyll $a$; lower values of chlorophyll $a / b$, chlorophyll a/C, nitrogen/heterotrophic [CFU] counts). In general the results for Station 2 were intermediate between Station 1 and Stations 3-7.

\section{Vertical Transect at Mid-Tide Level (Station 4)}

The results of the vertical transect carried out at Station 4 (mid tide level) are shown in Table 1. All the variables measured decreased with depth except chlorophyll $b$. The decreases were significant when analysed by 1 way anovars. Heterotrophic bacteria (CFU) showed a marked decrease falling to $29 \%$ of the surface value at $10 \mathrm{~cm}$. However the most significant decreases statistically were with chlorophylls $a$ and $c$ $(F=6.112$ and 6.385 respectively). Chlorophyll $b$ showed no decrease with depth $(F=0.1182, p>0.75)$. Carbon and nitrogen decreased to $86 \%$ and $79 \%$ respectively at $5 \mathrm{~cm}$ depth, and to $76 \%$ and $61 \%$ respectively at $10 \mathrm{~cm}$ depth. The percentage decreases for carbon and nitrogen were the same when tested statistically (2-way anovar; carbon/nitrogen against surface $/ 5 \mathrm{~cm} / 10 \mathrm{~cm}$. Interaction $F$ ratio $=2.213$, d. f. 2 , $36,0.25>\mathrm{P}>0.10$ ). However chlorophyll a decreased more rapidly than carbon (2-way anovar; carbon/ chlorophyll a against surface $/ 5 \mathrm{~cm} / 10 \mathrm{~cm}$. Interaction $\mathrm{F}$ ratio $=3.723$, d. f. $2,36,0.05>\mathrm{P}>0.025$ ) .

\section{Interrelationships Between Carbon, Nitrogen, Chlorophylls, Heterotrophic Bacteria (CFU) and Temperature}

The interrelationships between the different variables were assessed by firstly comparing pairs of variables by correlation analyses and secondly by comparing all the variables together with multiple linear regression analysis. The correlation coefficients between pairs of variables are shown in Table 2. Carbon, nitrogen and chlorophylls $a, b$ and $c$ were positively correlated and all of these correlations were highly significant $(\mathrm{P}<0.001)$. Heterotrophic bacteria (CFU) were not correlated with any variable. Temperature was not correlated with any variable except carbon.

When all the data were compared together using a multiple linear regression analysis (Snedecor and Cochran, 1967) with carbon as the dependent variable a highly significant positive multiple linear correlation
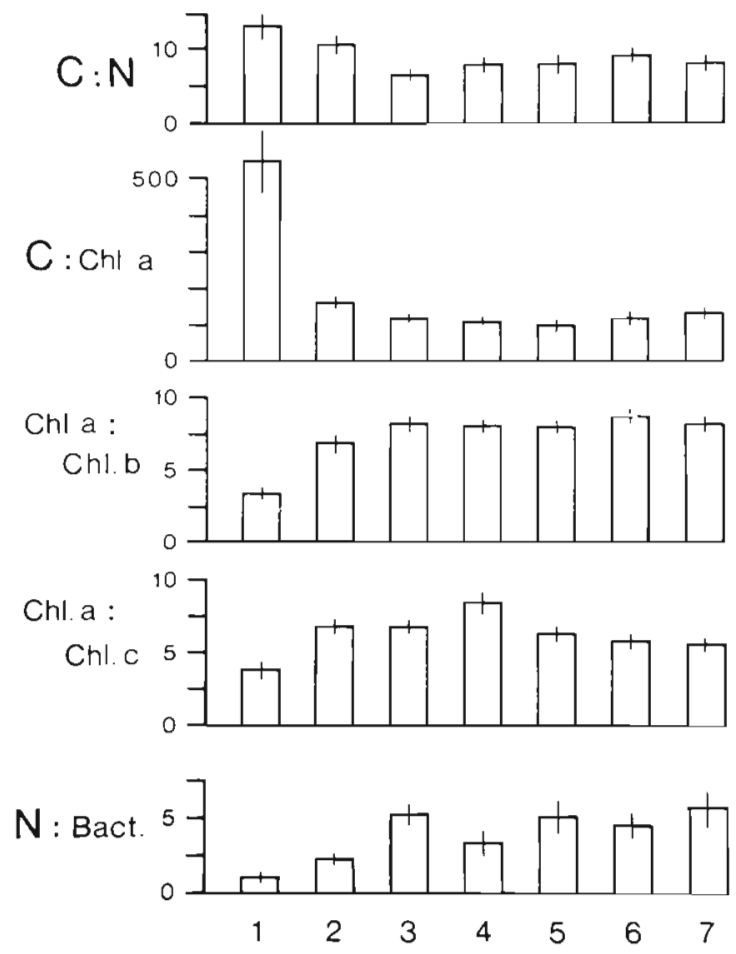

Fig. 3. Changes in ratios of carbon/nitrogen, carbon/ chlorophyll $a$, chlorophyll a/chlorophyll $b$, chlorophyll a/ chlorophyll $c$ and nitrogen/heterotrophic bacterial counts in surface sediment at Stations 1-7. Bars: standard errors. The number of readings on which the means are based are as in Fig. 1 
Table 1. Depth distribution at mid tide level (Station 4) of carbon, nitrogen, chlorophyll $a, b$, and $c$ ( $\mathrm{ug} \mathrm{g}^{-1} \mathrm{dry}$ sediment) and heterotrophic bacteria (no. $\times 10^{4} \mathrm{~g}^{-1}$ dry sediment). Means \pm standard deviations. Means for chlorophylls $a, b, c$ and heterotrophic bacteria (CFU) are based on 32 readings and for carbon and nitrogen on 16 readings. Figures in brackets are \% of surface values. $F$ ratio $=$ variance ratio of 1 -way analyses of variance on surface, $5 \mathrm{~cm}$, and $10 \mathrm{~cm}$ data

\begin{tabular}{|c|c|c|c|c|}
\hline \multirow[t]{2}{*}{ Parameter } & \multicolumn{3}{|c|}{ Depth in sediment } & \multirow{2}{*}{$\begin{array}{c}\text { Statistical analyses } \\
\text { Fratio }\end{array}$} \\
\hline & Surface & $5 \mathrm{~cm}$ & $10 \mathrm{~cm}$ & \\
\hline Carbon & $975.0 \pm 198.7$ & $\begin{array}{c}841.4 \pm 138.4 \\
(86 \%)\end{array}$ & $\begin{array}{c}741.4 \pm 128.6 \\
(76 \%)\end{array}$ & $3.837^{\circ}$ \\
\hline Nitrogen & $135.2 \pm 36.4$ & $\begin{array}{c}106.8 \pm 37.2 \\
(79 \%)\end{array}$ & $\begin{array}{c}83.04 \pm 30.49 \\
(61 \%)\end{array}$ & $3.941^{\circ}$ \\
\hline \multirow[t]{3}{*}{ Chlorophyll } & $8.719 \pm 1.779$ & $\begin{array}{c}6.439 \pm 2.016 \\
(74 \%)\end{array}$ & $\begin{array}{c}5.090 \pm 2.080 \\
(58 \%)\end{array}$ & $6.112^{\cdots}$ \\
\hline & $0.7200 \pm 0.4120$ & $\begin{array}{c}0.8214 \pm 0.2669 \\
(114 \%)\end{array}$ & $\begin{array}{c}0.7571 \pm 0.4764 \\
(105 \%)\end{array}$ & $0.1182^{\text {ns }}$ \\
\hline & $1.491 \pm 0.4577$ & $\begin{array}{c}1.004 \pm 0.3892 \\
(67 \%)\end{array}$ & $\begin{array}{c}0.6400 \pm 0.4891 \\
(43 \%)\end{array}$ & $6.385^{\cdots}$ \\
\hline $\begin{array}{l}\text { Heterotrophic bacteria } \\
\text { (CFU) }\end{array}$ & $39.93 \pm 23.99$ & $\begin{array}{c}22.18 \pm 21.75 \\
(56 \%)\end{array}$ & $\begin{array}{c}11.42 \pm 11.53 \\
(29 \%)\end{array}$ & $3.684^{\circ}$ \\
\hline
\end{tabular}

coefficient of $\mathrm{R}=0.7705$ was obtained $\left(\mathrm{F}_{5,40}=11.69\right.$, $\mathrm{P}<0.001) .60 \%$ of the total variation in the data was explained by this multiple linear regression (Draper and Smith, 1966). When chlorophyll $a, b$ and $c$ were omitted from the analysis the multiple correlation coefficient was still highly significant $(R=0.5916$, $\left.\mathrm{F}_{3,42}=7.538, \quad \mathrm{P}<0.001\right)$ but the total variation explained by the regression was only $35 \%$. When only one variable was removed from the analysis the variable which had the most marked effect was chlorophyll a which reduced the total variation explained by the multiple linear regression to $55 \%$.

\section{$\%$ of Sediment Organic Carbon Contained in Living Algae}

Chlorophyll values can be used to give an approximate estimate of the amount of living carbon contained in algae (Cadée and Hegeman, 1977). We have followed these authors in using chlorophyll a $\left(\mu \mathrm{g} \mathrm{g}^{-1}\right.$ sediment) $\times 20$ to estimate cell carbon content. Our results indicate that living algal carbon represents from 7 to $24 \%$ of the total sediment organic carbon (Table 3). Statistical analyses showed that the \% was not significantly different at Stations $2-7$ but was lower at Station 1 . There was also no significant difference in the $\%$ at the different depths in the vertical transect.

A regression analysis showed that the \% of sediment organic carbon not in living algae was inversely related to the chlorophyll a content of the sediment. This indicates that, in terms of total sediment organic carbon, there may be relatively less non-algal org. $\mathrm{C}$ when the chlorophyll a value is high. The regression equation for Stations $1-7$ (surface sediment) was $y=$ 74.94-0.9010 $\mathrm{x}$, where $\mathrm{x}=$ chlorophyll a as $\mu \mathrm{g} \mathrm{g}^{-1} \mathrm{dry}$ sediment and $y=\arcsin \left(\frac{[1-20 \mathrm{x}]}{\mathrm{C}} 100\right)$, where $\mathrm{C}=$

Table 2. Correlations between carbon, nitrogen, chlorophyll $a, b$, and $c\left(\mu g g^{-1} \mathrm{dry}\right.$ sediment), heterotrophic bacteria (CFU) (no. $\times 10^{4} \mathrm{~g}^{-1}$ dry sediment), and sediment temperature $\left({ }^{\circ} \mathrm{C}\right.$ ). The correlation coefficients assess the relationship between pairs of variables. 44 degrees of freedom in all cases

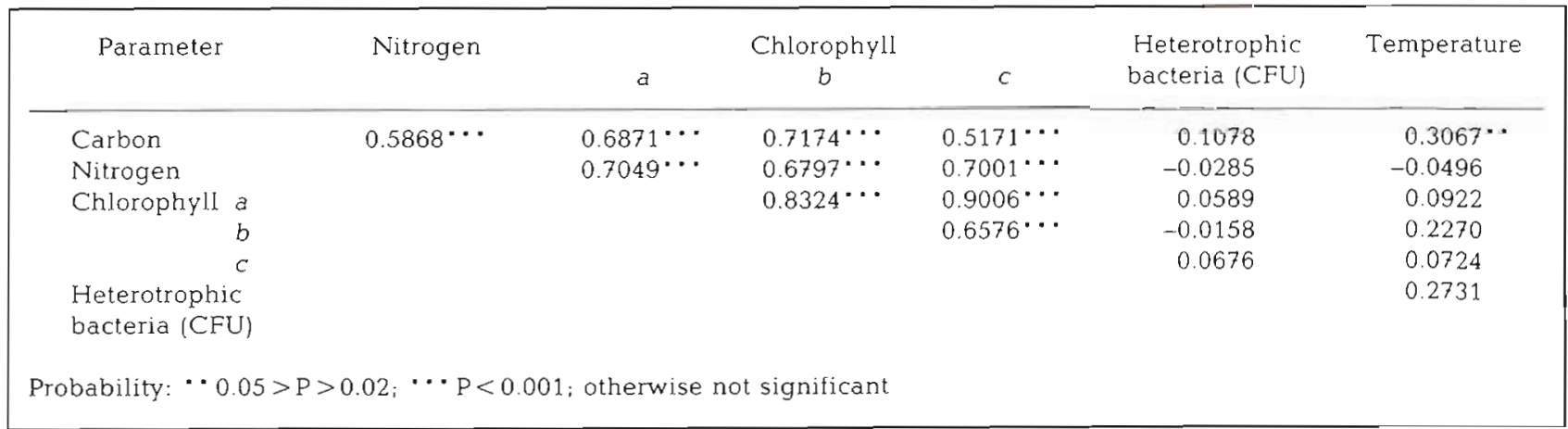


Table 3. Percentage of organic carbon contained in living algae (chl a $\mu \mathrm{g} \mathrm{g} \mathrm{g}^{-1}$ dry sediment $\times 20 / 100 \%$ ). (After Cadée and Hegeman, 1977)

\begin{tabular}{|c|c|c|c|c|c|c|c|c|}
\hline Station & & 1 & 2 & 3 & 4 & 5 & 6 & 7 \\
\hline Horizontal transect & $\begin{array}{l}\text { Mean } \\
\text { s.d. }\end{array}$ & $\begin{array}{l}6.905 \\
4.297\end{array}$ & $\begin{array}{r}16.204 \\
6.335\end{array}$ & $\begin{array}{r}18.521 \\
3.155\end{array}$ & $\begin{array}{l}20.96 \\
5.578\end{array}$ & $\begin{array}{r}24.113 \\
8.515\end{array}$ & $\begin{array}{l}21.933 \\
12.168\end{array}$ & $\begin{array}{r}19.548 \\
9.515\end{array}$ \\
\hline \multicolumn{2}{|c|}{ Depth in sediment } & & & Surface & \multicolumn{2}{|r|}{$5 \mathrm{~cm}$} & \multicolumn{2}{|c|}{$10 \mathrm{~cm}$} \\
\hline \multicolumn{2}{|c|}{$\begin{array}{l}\text { Vertical transect } \\
\text { (at Station } 4 \text { ) }\end{array}$} & \multicolumn{2}{|c|}{$\begin{array}{l}\text { Mean } \\
\text { s.d. }\end{array}$} & $\begin{array}{c}19.01 \\
6.862\end{array}$ & & $\begin{array}{r}16.223 \\
7.390\end{array}$ & \multicolumn{2}{|c|}{$\begin{array}{r}14.356 \\
6.482\end{array}$} \\
\hline
\end{tabular}

total sediment organic carbon in $\mu g^{-1}$ dry sediment. This regression was highly significant, $t=5.678$ with 44 d.f., $P<0.001$. The arcsin transformation was used because $\frac{(1-20 x)}{C} 100$ is a \% (Sokal and Rohlf, 1969).

A similar analysis on the vertical transect data gave a regression equation of $y=79.24-1.897 x$ which was also highly significant $\mathrm{t}=6.761$ with 19 d.f., $\mathrm{P}<0.001$.

\section{DISCUSSION}

There is surprisingly little information on the horizontal distribution of sand microorganisms on sandy intertidal beaches between high and low tide. A number of authors (Pearse et al., 1942; Pamatmat, 1968; Steele and Baird, 1968; Anderson and Meadows, 1969; Meyer-Reil et al., 1978; de Jonge, 1980) report results from isolated intertidal stations, but only Meadows and Anderson (1968), Westheide (1968), Pugh et al. (1974) and Rheinheimer (1977) have conducted a systematic shore transect from high to low tide.

Meadows and Anderson (1968) using direct microscopy reported low populations of diatoms at EHWS which increased in the intertidal zone with a peak at about mid-tide level. Westheide (1968) employing viable counts reported highest levels of bacteria, yeasts and actinomycetes towards and above mean high tide. Pugh et al. (1974) also observed that bacterial numbers decreased down the intertidal zone. In neither of the studies by Meadows and Anderson (1968) and Westheide (1968) were measurements made of chlorophylls, carbon or nitrogen. Pugh et al. (1974) could find no change in carbon at different intertidal stations. We report statistically significant peaks in chlorophylls a, $b$ and $c$, carbon and nitrogen at mean high tide and mean low tide levels and significantly more heterotrophic bacteria (CFU) at high tide. At EHWS however in the splash zone the chlorophylls, carbon and nitrogen were all very low. De Jonge (1980) measured organic carbon to chlorophyll a ratios from 6 isolated intertidal stations in the Ems estuary and obtained values that broadly agree with our data (Fig. 3). He did not however, conduct a systematic shore transect.

Our vertical transect results (Table 1) - which show a reduction in chlorophyll $a$, carbon, nitrogen and heterotrophic bacteria (CFU) with depth - are broadly in agreement with previous studies on sandy beaches (Pamatmat, 1968; Steele and Baird, 1968; Westheide, 1968; Schmidt and Westheide, 1971; Cadée and Hegeman, 1974; Rheinheimer, 1977). We have also measured chlorophylls $b$ and $c_{i}$ whereas chlorophyll $c$ showed a decrease with depth, chlorophyll b remained constant. Our chlorophyll results therefore suggest that diatoms decrease with depth while microscopic euglenophytes and chlorophytes remain fairly constant to $10 \mathrm{~cm}$, the deepest level sampled (Dawson, 1966). Taylor and Gebelin (1966) also carried out a detailed study of the vertical distribution of plant pigments in intertidal sediments. Changes in chlorophylls $a$ and $c$, phyophytin-a, carotene and several Xanthophyll pigments were recorded. In general, highest concentrations of all pigments were found in the upper $\mathrm{mm}$. Chlorophylls a and $c$ and fucoxanthin concentrations decreased with depth whereas diatoxanthin, diadinoxanthin and carotene did not.

Our data were submitted to detailed statistical analyses by correlation and multiple linear regression methods. Carbon, nitrogen, chlorophylls $a, b$ and $c$ were all strongly correlated with each other, however heterotrophic bacteria (CFU) were not correlated with any other variable and temperature was only correlated with carbon. The lack of correlation between bacterial (CFU) counts and any other assayed parameter may reflect the limitations of the dilution plate counting procedure which substantially underestimates numbers of viable heterotrophic bacteria in natural environments. The multiple linear regression analysis using carbon as the dependent variable showed a highly significant positive correlation which represented $60 \%$ of the total variation in the data. When any one variable was removed from the multiple linear regression analysis chlorophyll a had the most 
marked effect. The results of these statistical analyses taken together indicate that the photosynthetic microorganisms are the most important determinants of the carbon and nitrogen levels in intertidal sands. The only comparable studies are by Steele and Baird (1968) which show a positive correlation between chlorophyll a and carbon, and by Pugh et al. (1974) who, similar to the present study, could find no relation between carbon and heterotrophic bacteria either by principle components analysis or by multiple regression analysis.

Cadée and Hegeman (1977) have used sediment chlorophyll $a \times 20$ to give an approximate estimate of algal carbon content. Using this estimate, living algal carbon represents $7-24 \%$ of the total sediment organic carbon which compares with 3-9\% quoted by these authors. There is also an inverse relationship between the $\%$ of sediment organic carbon not in living algae and the chlorophyll a content of the sediment. This relationship was not reported by Cadée and Hegeman (1977) and does not appear to have been previously recorded. It is not clear at present how this relationship should be interpreted. The sediment organic carbon not contained in living algae will consist of dead algal carbon, living and dead non-algal microbial carbon and carbon in other detrital material. Our inverse relationship shows that one or more of these components decreases as the chlorophyll a content of the sediment increases. There are a number of possible explanations for this effect. It may reflect some aspect of competition between algae and other microorganisms (Meadows and Anderson, 1979 p. 229). For example, living pelagic diatoms are often free of bacteria (Droop and Elson, 1966; Sieburth, 1975) while bacteria attach to dead or senescent cells (Sieburth et al, 1974). It has been suggested (Sieburth, 1968) that healthy diatoms secrete glycollic acid which maintains an acid microzone at the cell-water interface and that this inhibits bacterial growth. It is known that algal and bacterial colonies often develop in close association within crevices and cracks on sand grain surfaces where they are protected from abrasion (Meadows and Anderson, 1968; Anderson and Meadows, 1969). Consequently the effects reported by Sieburth et al. (1974) may be magnified in the localised microenvironments found on sand grain surfaces (Anderson and Meadows, 1978).

\section{LITERATURE CITED}

Anderson, J. G., Meadows, P. S. (1969). Bacteria on intertidal sand grains. Hydrobiologia 33: 33-46

Anderson, J. G. Meadows, P. S. (1978). Microenvironments in marine sediments. Proc. R. Soc. Edinb. 76B: 1-16
Cadée, G. C., Hegeman, J. (1974). Primary production of the benthic microflora living on tidal flats in the Dutch Wadden Sea. Neth. J. Sea Res. 8: 260-291

Cadée, G. C. Hegeman, J. (1977). Distrubution of primary production of the benthic microflora and accumulation of organic matter on a tidal flat area, Balgzand, Dutch Wadden Sea. Neth. J. Sea Res. 11: 24-41

Dawson, E. Y (1966). Marine botany: An introduction, Holt, Rinehart and Winston Inc., New York

de Jonge, V. N. (1980). Fluctuations in the organic carbon to chlorophyll a ratios for estuarine benthic diatom populations. Mar. Ecol. Prog. Ser. 2: 345-353

Draper, N. R., Smith, H. (1966). Applied regression analysis John Wiley and Sons, New York

Droop, M. R., Elson, K. G. R. (1966). Are pelagic diatoms free from bacteria? Nature, Lond. 211: 1096-1097

Meadows, P. S., Anderson, J. G. (1968). Microorganisms attached to marine sand grains. J. mar. biol. Ass. U. K. 48 $161-175$

Meadows, P. S., Anderson, J. G. (1979). The microbiology of interfaces in the marine environment. Progr. Industrial Microbiol. 15: 207-265

Meadows, P. S., Campbell, J. I (1972). Habitat selection by aquatic invertebrates. Adv. mar. Biol. 10: 271-382

Meyer-Reil, L. A., Dawson, R., Liebezeit, G., Tiedge, H. (1978). Fluctuations and interactions of bacterial activity in sandy beach sediments and overlying waters. Mar. Biol. 48: $161-171$

Munro, A. L. S., Wells, J. B. J., McIntyre, A. D. (1978). Energy flow in the flora and meiofauna of sandy beaches. Proc. $R$. Soc. Edinb. B76: 297-315

Pamatmat, M. M. (1968). Ecology and metabolism of a benthic community on an intertidal sandflat. Int. Revue ges. Hydrobiol. 53: 211-298

Parsons, T R. Strickland, J. D. H. (1963). Discussion of spectrophotometric determination of marine plant pigment with revised equations for ascertaining chlorophylls and carotenoids. J. mar Res. 21. 155-163

Pearse, A. S., Humm, M. J., Wharton, G. W. (1942). Ecology of sand beaches at Beaufort, N. C. Ecol. Monogr 12: 135-190

Pugh, K. B., Andrews, A. R., Gibbs, C. F., Davis, S. J., Floodgate, G. D. (1974). Some physical, chemical, and microbiological characteristics of two beaches of Anglesey. J. exp. mar. Biol. Ecol. 15: 305-333

Rheinheimer, G. (1977). Bakteriologisch-ökologische Untersuchungen in Sandstränden an Nord- und Ostsee. Bot. Mar 20: 385-400

Schmidt, P., Westheide, W. (1971). Études sur la répartition de la microfaune et de la microflore dans une plage de l'ile de sylt (Mer du Nord). Vie Milieu 22 (Suppl.): 449-464

Sieburth, J. M. (1968). The influence of algal antibiosis on the ecology of marine microorganisms. In: Droop, M. R., Wood, E. J. F. (eds.) Advances in microbiology of the sea Academic Press, New York, pp. 63-94

Sieburth, J. M. (1975). Microbial seascapes, University Park Press, Baltimore

Sieburth, J. M., Brooks, R. D., Gressner, R. V., Thomas, C. D., Tootle, J. L. (1974). Microbial colonisation of marine plant surfaces as observed by scanning electron microsopy. In Colwell, R. R., Morita, R. Y (eds.) Effects of the ocean environment on microbial activities. University Park Press, Baltimore, pp. $418-432$

Snedecor, G. W., Cochran, W. G. (1967). Statistical methods, 6 th ed. Iowa State Iniversity Press, Ames, Iowa

Sokal, R. R., Rohlf, F. J. (1969). Biometry: The principles and practice of statistics in biological research, W. H. Freeman. San Francisco 
Steele, J. H., Baird, I. E. (1968). Production ecology of a sandy beach. Limnol. Oceanogr. 13: 14-25

Strickland, J. D. N., Parsons, T. R. (1968). A practical handbook of seawater analysis, Fisheries Research Board of Canada, Ottawa, Bulletin 167

Taylor, W. R., Gebelein, C. D. (1966). Plant pigments and light penetration in intertidal sediments. Helgoländer wiss. Meeresunters. 13: 229-237

Westheide, W. (1968). Zur quantitativen Verteilung von Bakterien und Hefen in einem Gezeitenstrand der Nordseeküste. Mar. Biol. 1: 336-347

This paper was submitted to the editor; it was accepted for printing on July 20, 1981 